\title{
Yeast spores seem to be involved in biological phosphate removal: a microscopic in situ case study
}

\author{
Hannes Melasniemi ${ }^{1,2}$ and Anne Hernesmaa ${ }^{1} \dagger$
}

Author for correspondence: Hannes Melasniemi. Tel: +358 9 4513845. Fax: +35894513856. e-mail: hannes.melasniemi@hut.fi

1 University of Helsinki, Department of Applied Chemistry and Microbiology, PO Box 56 FIN-00014 University of Helsinki, Finland

2 Helsinki University of Technology, Laboratory of Environmental Engineering, PO Box 6100, FIN-02015 HUT, Finland
The principal polyphosphate-accumulating organism (PAO) in a biologicalphosphate-removal activated-sludge process was assessed microscopically. The organism was recognized by its distinct morphotype most easily after polyphosphate staining. The PAO occurred in large, homogeneous clusters. The cells of the PAO were the biggest cells abounding in the sludge - clearly bigger than average sludge bacteria. Typical of the principal PAO was a variation of cell size, even in fresh sludge. In acetate minimal medium containing ampicillin, the original principal PAO clusters were converted to clusters of clearly larger, polyphosphate-containing, vegetative yeast-like cells. Cycloheximide addition inhibited this and caused flock disintegration, disappearance of the principal PAO clusters and growth of free bacteria. The cell wall of the principal PAO was not of the usual bacterial character. It showed anomalous Gram staining, stained for chitin (not found in bacteria) and bound concanavalin A, like cell walls of many yeasts. In addition, the PAO cell wall was resistant to lysozyme, but sensitive to an enzyme mixture that lyses yeast cell walls. It was concluded that the principal PAO cells in the studied sludge were clustered spores of a yeast.

Keywords: biological-phosphate removal, polyphosphate, activated sludge, yeast spores

\section{INTRODUCTION}

The first observations on biological-phosphate removal (BPR) in activated sludge, in excess of the amount needed for the synthesis of new sludge biomass, were reported by Srinath et al. (1959). The basic mechanism of BPR was, some 20 years later, inferred to be the accumulation of phosphate as polyphosphate (polyP) in the cells of activated-sludge micro-organisms (Fuhs \& Chen, 1975; Buchan, 1981). Conventionally, it has been assumed that BPR sludges with high P removal capability would be enriched with a single dominant group of polyP-accumulating organisms (PAOs; Mino et al., 1998). This assumption is based on the recurrent

\footnotetext{
Present address: University of Helsinki, Department of Biosciences, Division of General Microbiology, PO Box 56, FIN-00014 University of Helsinki, Finland

Abbreviations: $\mathrm{BOD}_{7}$, seven-day biological oxygen demand; $\mathrm{BPR}$ biological-phosphate removal; COD, chemical oxygen demand; DAPI, 4',6diamidino-2-phenylindole; PAO, polyphosphate-accumulating organism; polyP, polyphosphate; UCT, University of Cape Town.
}

microscopic finding of a specific morphotype of PAO with big, coccoid cells arranged in seemingly homogeneous, distinct, grape-like clusters that contain the bulk of polyP in the sludge (Fuhs \& Chen, 1975 ; Buchan, 1981, 1983; Duncan et al., 1988; Beacham et al., 1990; Streichan et al., 1990; Jenkins et al., 1993).

Acinetobacter spp. are so far the best known polyPaccumulating bacteria isolated, and for several years Acinetobacter was considered as the principal PAO in $\mathrm{BPR}$. Although polyP accumulation in laboratorygrown Acinetobacter is well established, the significance of this bacterial genus in genuine waste water treating BPR processes has, however, been challenged (Cloete \& Steyn, 1988; Auling et al., 1991; Wagner et al., 1994; Tandoi et al., 1998). Several other bacteria capable of polyP accumulation have been isolated from BPR sludge (Lötter \& Murphy, 1985; Streichan et al., 1990; Nakamura et al., 1995; Stante et al., 1997). Even though BPR in activated sludge has been known as a phenomenon for 40 years and there have been working full-scale BPR plants for about 20 years, the roles of different bacteria are still obscure (Toerien et al., 1990; van 
Loosdrecht et al., 1997; Mino et al., 1998), as is the identity of the PAOs involved.

In a previous study (Melasniemi et al., 1998) it was shown that acinetobacters did not contain significant amounts of polyP in a UCT (University of Cape Town)type nutrient-removal activated-sludge process treating municipal waste water. Instead, the stainable polyP in the sludge under process conditions was found almost exclusively in microbial cells corresponding to the descriptions of the grape-like clusters forming PAO so often seen to predominate in real waste water treating BPR processes (Fuhs \& Chen, 1975; Buchan, 1981, 1983; Duncan et al., 1988; Beacham et al., 1990; Streichan et al., 1990; Jenkins et al., 1993). In the present study the organism was assessed in situ in the sludge using differential microscopic methods. Results reported here suggest that the predominant $\mathrm{PAO}$ in the process studied was not a bacterium at all.

\section{METHODS}

Sludge samples. Activated sludge of a biological P- and Nremoval process situated at the Suomenoja waste-water treatment plant, Southern Finland, was studied. The waste water coming to the plant was low-strength municipal waste water (235000 population equivalents) containing a fairly low proportion $(8 \%)$ of industrial waters and having no known exceptional properties. The pre-settled influent conducted to the experimental process contained as long-term means $\left(\mathrm{mg} \mathrm{l}^{-1}\right)$ : total P, 5.6; soluble P, 2.9; $\mathrm{PO}_{4}-\mathrm{P}, 3 \cdot 0$; total N, 40; $\mathrm{NH}_{4}-\mathrm{N}, 35$; total chemical oxygen demand (COD), 300; soluble COD, 140 and seven-day total biological oxygen demand $\left(\mathrm{BOD}_{7}\right), 130$. In addition to human excreta, grey waters and environmental runoff waters, there were no known sources of yeasts in the influent. The technical scale $\left(42 \mathrm{~m}^{3}\right)$ process with a conventional UCT configuration (for closer description, see Melasniemi et al., 1998) was run for several years as a pure BPR process, i.e. without the addition of any phosphate-precipitating chemicals. Mean sludge age was $17 \cdot 5 \mathrm{~d}$ and mean annual temperature was $15^{\circ} \mathrm{C}$. Mean reductions (pre-settled influent - post-settled effluent) were (\%) : total P, 64; soluble P, 55; $\mathrm{PO}_{4}-\mathrm{P}, 77$; total $\mathrm{N}, 41$; total COD, 81 and total $\mathrm{BOD}_{7}, 89$. Grab samples of mixed liquor (suspended solids $\sim 4.5 \mathrm{~g} \mathrm{l}^{-1}$ ) were taken from the aerobic basin.

Microscopy and differential stainings. Fluorescence and phase-contrast microscopy were done with an Olympus AX70 Provis microscope fitted with UV and U-MNG filter blocks and $60 \times$ and $100 \times$ objectives. Bright-field microscopy was with an Olympus $\mathrm{BH}-2$ microscope fitted with a $100 \times$ objective. Slides on Fujichrome 100 were digitized with a Polaroid SprintScan scanner and an Adobe Photoshop 3.0 program was used to handle the images.

PolyP-containing cells were visualized with 4',6-diamidino-2phenylindole (DAPI, $50 \mu \mathrm{g} \mathrm{ml}^{-1}$; Allan \& Miller, 1980) for fluorescence microscopy and with toluidine blue (colour index 52040; Drews, 1983) for bright-field microscopy. Samples for toluidine blue staining were heat fixed before staining and destained afterwards for $1-2 \mathrm{~min}$ with $1 \% \mathrm{H}_{2} \mathrm{SO}_{4}$ to reduce staining of the sludge background. Gram staining was done by the rapid method described by Hendrickson \& Krenz (1991).

Calcofluor white M2R (colour index 40622, Sigma) was used as a stain for $\beta$-1,4-hexapyranose polysaccharides essentially as described by Pringle (1991). Calcofluor was dissolved by adding $20 \mu \mathrm{l} 0 \cdot 1 \mathrm{M} \mathrm{NaOH}$ to $1 \mathrm{ml}$ of calcofluor suspension $\left(1 \mathrm{mg} \mathrm{ml}^{-1}\right)$ in water, to obtain a solution with a $\mathrm{pH}$ of approximately 8 . Calcofluor solution $(400 \mu \mathrm{l})$ was added to sludge sample $(200 \mu \mathrm{l}$ mixed liquor) and the mixture was incubated at room temperature $\left(\sim 22{ }^{\circ} \mathrm{C}\right) \leqslant 30 \mathrm{~min}$. The sludge was centrifuged with a microcentrifuge, washed five times with $1 \mathrm{ml}$ deionized water, resuspended in $200 \mu \mathrm{l}$ water and inspected by fluorescence microscopy using UV excitation.

Tetramethyl rhodamine-conjugated concanavalin A (Molecular Probes) was used to stain cell-wall mannans essentially as described by Tkacz et al. (1971). The sludge sample $(200 \mu \mathrm{l}$ mixed liquor) was centrifuged and resuspended in $180 \mu 11 \mathrm{M}$ $\mathrm{NaCl}$ and $20 \mu \mathrm{l}$ concanavalin A conjugate stock solution $\left(1 \mathrm{mg} \mathrm{ml}^{-1}\right)$ was added. After $30 \mathrm{~min}$ incubation at room temperature the sludge was centrifuged, washed twice with $1 \mathrm{ml} 1 \mathrm{M} \mathrm{NaCl}$, resuspended in $200 \mu \mathrm{l}$ water and inspected by fluorescence microscopy using green excitation.

Antibiotic susceptibility. The minimal Acinetobacter enrichment medium described by Towner (1992) was modified by replacing the original mineral base with the trace element solution of Kotai $\left(1971 ; 1 \mathrm{ml} \mathrm{l}^{-1}\right)$ and raising the $\mathrm{pH}$ of the medium to $7 \cdot 0$. The medium was used with addition of ampicillin $\left(1 \mathrm{~g} \mathrm{l}^{-1}\right)$ or cycloheximide $\left(50 \mathrm{mg} \mathrm{l}^{-1}\right)$, or without antibiotics. The medium $(5 \mathrm{ml})$ was inoculated with sludge $\left(0.5 \mathrm{ml}\right.$ mixed liquor) and the cultures were incubated at $28^{\circ} \mathrm{C}$ shaken at 150 r.p.m. Changes in the sludge were monitored microscopically over several days.

Cell-wall digestion. Sludge ( $1 \mathrm{ml}$ mixed liquor) was stained for polyP with DAPI, washed with Tris/HCl buffer $(25 \mathrm{mM}$, $\mathrm{pH} 7 \cdot 0$ ) and resuspended in $1 \mathrm{ml}$ of the same buffer. Lysozyme from egg white (Sigma) or lysing enzymes from Trichoderma harzianum (Sigma) were added to $0.5 \mathrm{ml}$ aliquots (final concentrations 26 and $16 \mathrm{mg} \mathrm{ml}^{-1}$, respectively) and the mixtures were incubated at room temperature for 6 and $2 \mathrm{~d}$, respectively. Changes in the sludge were monitored microscopically.

\section{RESULTS}

\section{Identification marks}

PolyP-containing micro-organisms were visualized in the BPR-activated sludge of a UCT-type process by two different polyP stains, DAPI for fluorescence microscopy

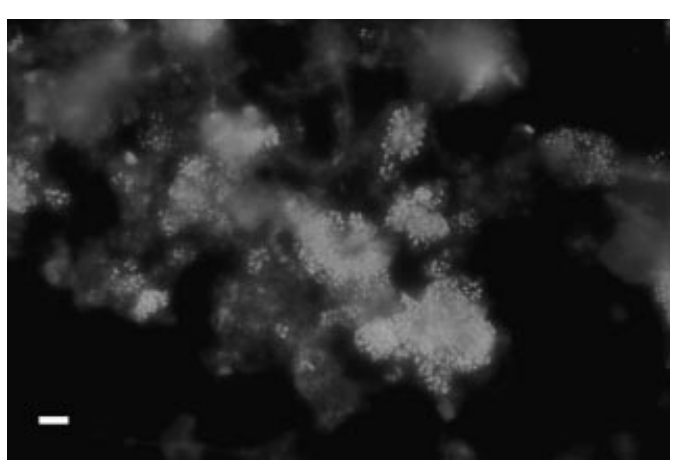

Fig. 1. Clusters of the principal $P A O$ in fresh BPR-activated sludge purifying municipal waste water. PolyP is stained with DAPI. The image was obtained by fluorescence microscopy. Bar, $10 \mu \mathrm{m}$. 


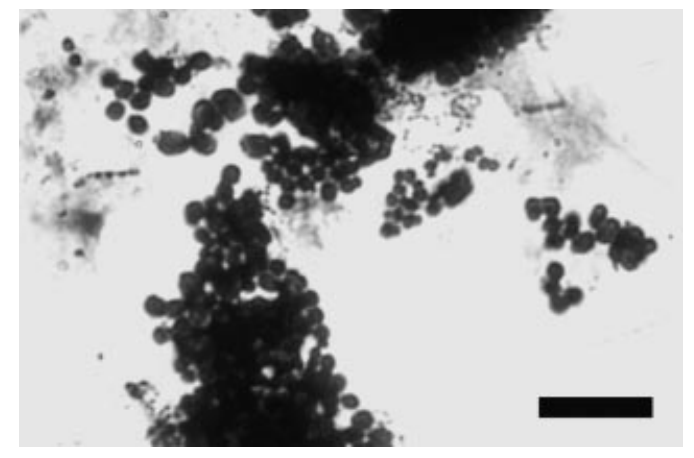

Fig. 2. Principal $P A O$ clusters in fresh sludge, stained for polyP with toluidine blue. Note the size variation of the principal PAO cells. The image was obtained by bright-field microscopy. Bar, $10 \mu \mathrm{m}$.

and toluidine blue for bright-field microscopy. Stained with DAPI, polyP-containing cells were revealed by their intense yellow fluorescence against the less intense bluish background of sludge cells containing no polyP. Stained with toluidine blue, polyP-containing cells were revealed by their dark blue or purple colour against bluish sludge background. Both staining methods gave the same basic result: almost the whole of the microscopically detected polyP in the sludge was consistently (since 1995, when we started to observe the process) found in microbial cells that occurred in large clusters (Figs 1 and 2). These clusters were homogeneous in appearance and seemed to be formed of cells of just a single type of microorganism, referred to hereafter as the sludge principal PAO.

The cells of the principal PAO were of a distinct morphotype. They were the biggest cells abounding in the sludge - clearly bigger than average sludge bacteria. The shape of the cells was roundish, ranging from oval to coccoid. The lengths of individual principal PAO cells in fresh sludge samples stained with toluidine blue were in most cases between 1 and $2 \mu \mathrm{m}$. The size of the cells was, however, not constant, even in fresh sludge samples. The size of the PAO cells making up a cluster could vary considerably (Fig. 2), as could the mean size of cells in different clusters. When sludge (mixed liquor) was incubated in the laboratory shaken at room temperature without any additions, the principal PAO cells often started gradually to enlarge or swell. The mostly slight swelling of the cells was associated with their more or less oval form turning to even more rounded and coccoid. In undisturbed sludge samples, the principal PAO seemed always to occur in fairly globular clusters, never as individual free cells. The number of individual PAO cells in the clusters varied from 20-30 to more than 1000 and seemed in most cases to be between 100 and 500. Because of the aforementioned identification marks and the fact that very little polyP could be detected elsewhere in the sludge, the principal PAO clusters were easy to recognize in polyPstained samples. With some practice, the clusters could

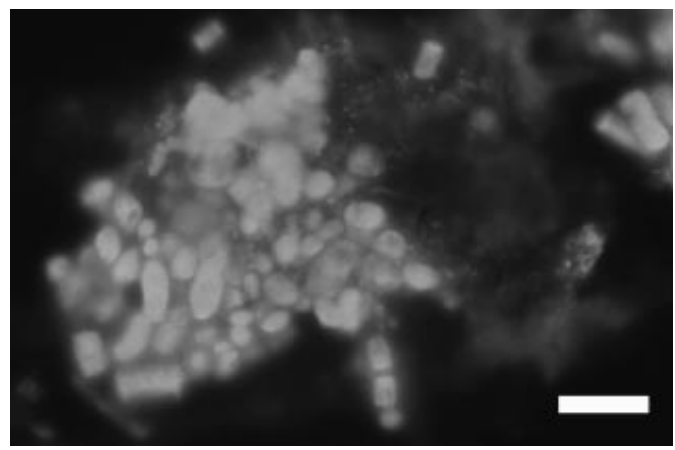

Fig. 3. Vegetative yeast-like, polyP-containing clustered cells in sludge incubated for $10 \mathrm{~d}$ in acetate minimal medium containing ampicillin. DAPI staining. Bar $10 \mu \mathrm{m}$.

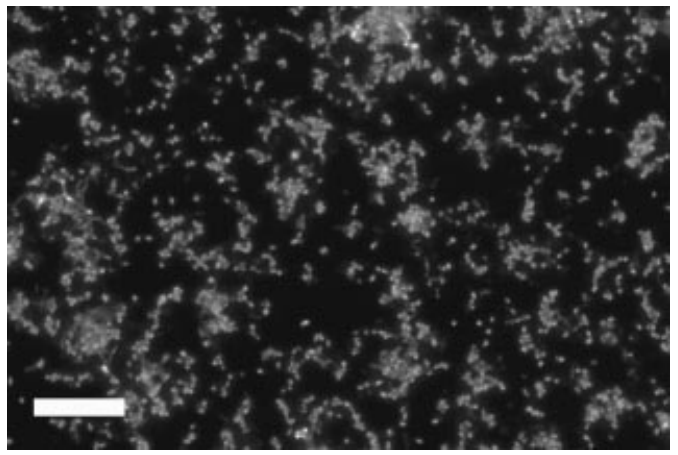

Fig. 4. Flock disintegration and production of free bacteria in sludge incubated for $10 \mathrm{~d}$ in acetate minimal medium containing cycloheximide. The image was obtained by DAPI staining. Bar, $10 \mu \mathrm{m}$.

be recognized also in phase-contrast, or even unstained under bright-field illumination (not shown).

\section{Morphological transformation}

When fresh sludge was transferred to liquid acetate minimal medium containing ampicillin, the original PAO cells tightly packed in the grape-like clusters were converted to considerably bigger cells containing polyP (Fig. 3). The transformation started unobtrusively and asynchronously at various points on the edges of the clusters, but after a few days the clusters of the principal PAO had been replaced by clusters of the still bigger cells. Other parts of the sludge seemed to remain fairly unchanged and to retain the original flock structure. The length of the cells produced by this morphological transformation was approximately $5 \mu \mathrm{m}$ or more, but less than $10 \mu \mathrm{m}$, and the appearance of the cells was that of vegetative yeast cells (Fig. 3). If ampicillin was replaced by cycloheximide, sludge flock structure disintegrated, the principal PAO clusters vanished, and there was an abundant growth of free bacteria, many containing polyP (Fig. 4). Finally, if both antibiotics 


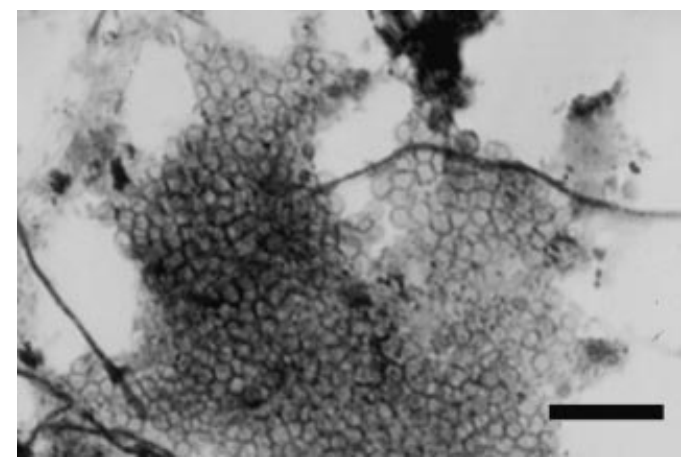

Fig. 5. A Gram-stained cluster of the principal $P A O$ in fresh sludge. The image was obtained by bright-field microscopy. Bar, $10 \mu \mathrm{m}$.

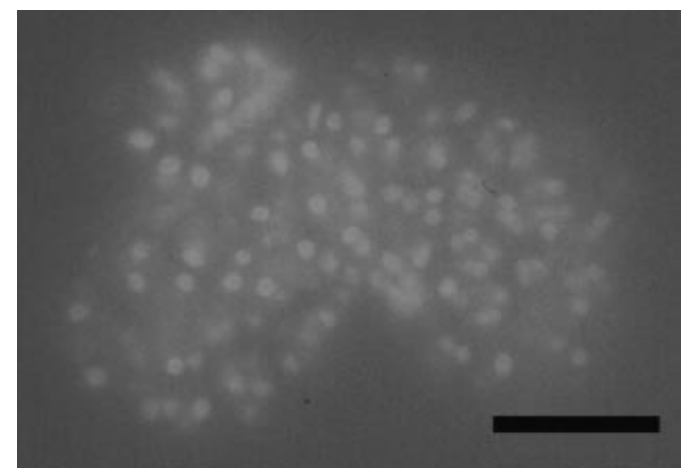

Fig. 6. Affinity of the chitin-binding fluorescent dye calcofluor white M2R to principal PAO cells. Sludge for the experiment was taken from mixed liquor preincubated in the laboratory, shaken 150 r.p.m. at $\sim 22^{\circ} \mathrm{C}$ for 4 d. Bar, $10 \mu \mathrm{m}$.

were omitted, no striking changes were observed. Initial principal PAO cell clusters, although showing some swelling and staining less intensely for polyP, could still be found even after incubation for a month (not shown).

\section{Cell-surface characteristics}

The cell surface of the principal PAO was studied by staining, affinity labelling and by enzymic digestion. The response of the principal PAO in Gram staining was anomalous: the cells did not stain Gram-positive or properly Gram-negative. The surface of the PAO seemed to resist Gram staining and the clusters took only a shade of orange. Even this pale staining might better reflect staining of a matrix between the cells than staining of the cell wall itself (Fig. 5). Gram-stained clusters of the principal PAO did not show much space between the individual cells and clearly showed the absence of other microbes in the clusters.

The $\beta$-1,4-hexapyranose polysaccharide-binding fluorescent dye calcofluor was bound in the sludge to clusters of cells having the size, shape and arrangement of the principal PAO cells (Fig. 6). The intensity of the

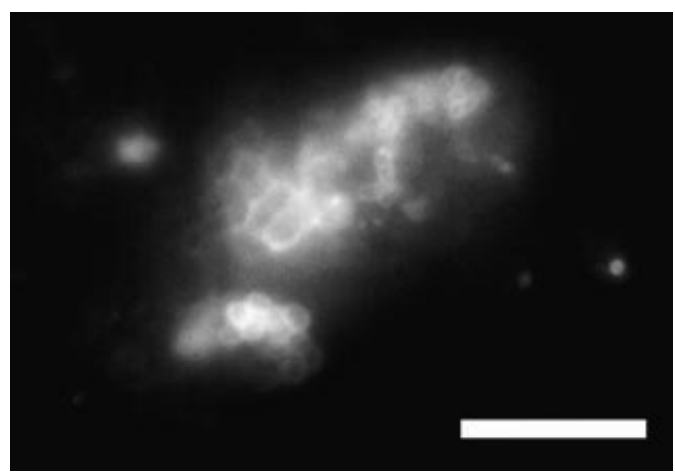

Fig. 7. Affinity of the mannan-binding fluorescent concanavalin A-rhodamine conjugate to principal PAO cells in fresh sludge. Bar, $10 \mu \mathrm{m}$.

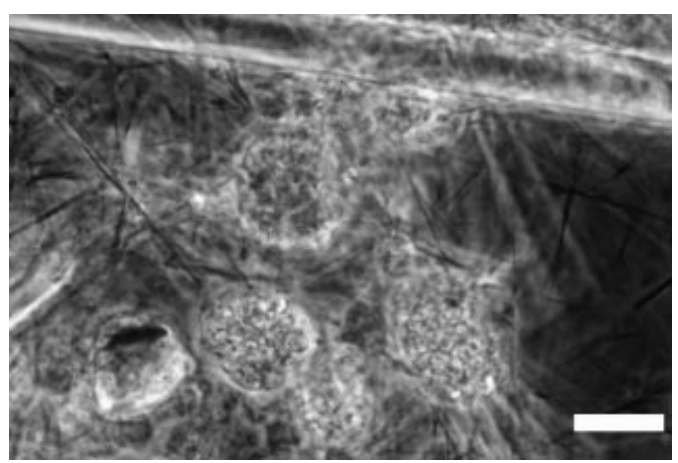

Fig. 8. Small globular clusters of principal PAO cells showing the lysozyme resistance of the organism. Sludge was incubated for $6 \mathrm{~d}$ with an excess of the bacterial cell-wall-degrading enzyme. Note the crystallized needles of enzyme. Sludge for the experiment was taken from mixed liquor preincubated in the laboratory for $4 \mathrm{~d}$. The image was obtained by phasecontrast microscopy. Bar, $10 \mu \mathrm{m}$.

fluorescence signal from the clusters was low, however, and the signal from individual cells in a cluster was variable. No signal was obtained elsewhere in the sludge. Affinity labelling of sludge with a fluorescent concanavalin A-rhodamine conjugate gave in essence the same result: concanavalin A was bound specifically to clustered cells with the morphological identification marks of the principal PAO (Fig. 7).

Fig. 8 shows small globular clusters of principal PAO cells in sludge incubated for $6 \mathrm{~d}$ in the presence of lysozyme. The amount of typical bacterial cells discernible in the sludge was diminished strongly by this treatment. The amount and appearance of the clustered principal PAO cells seemed, however, unaffected by lysozyme. Neither did the treatment significantly affect their polyP (not shown) stained with DAPI prior to the digestion in order to secure correct recognition. The needle-like rods in Fig. 8 are crystals of lysozyme formed during the incubation. In contrast to its resistance to lysozyme, the principal PAO was sensitive to the enzyme 




Fig. 9. Formation of spheroplasts from principal PAO cells by 'lysing enzymes'. Fresh sludge was incubated for $2 \mathrm{~d}$ with the yeast cell-wall-degrading enzyme mixture. The image was obtained by phase-contrast microscopy. Bar, $10 \mu \mathrm{m}$.

mixture 'lysing enzymes'. In the presence of this lytic enzyme mixture the PAO cells started to swell and produced round, balloon-like spheroplasts (Fig. 9) before vanishing.

\section{DISCUSSION}

\section{Rationale of the in situ approach}

A single dominant group of PAOs has been suggested to be present in BPR sludges treating genuine waste water due to the recurrent observations that the bulk of polyP is in a specific morphotype of micro-organism with big coccoid cells arranged in distinctive grape-like clusters (Fuhs \& Chen, 1975; Buchan, 1981, 1983; Duncan et al., 1988; Beacham et al., 1990; Streichan et al., 1990; Jenkins et al., 1993; Melasniemi et al., 1998). This organism was initially associated with Acinetobacter, which set off a boom of research on this bacterium. Today it seems likely, however, that the clustered PAO cannot be isolated by conventional bacteriological procedures, since no bacterial pure culture isolated so far has shown the expected PAO characteristics (Mino et al., 1998). Hitherto it has been possible to observe the grape-like clusters forming PAO only under very peculiar growth conditions, i.e. in situ in BPR sludge. In addition, due to different physiological conditions, it may not always be possible for the organism to accumulate polyP under laboratory conditions. This is why we decided to study the principal $\mathrm{PAO}$ in its native habitat. By observing the response of the PAO to different stimuli, as well as by probing its cell surface using differential staining methods, we hoped to gather some clues as to the nature of the organism, which would assist later in devising a proper procedure for its isolation.

\section{Established PAO characteristics match with fungal spores}

The PAOs mediating BPR have been conventionally thought of as polyP-accumulating bacteria. There is, however, no a priori reason why BPR had to rely (solely) on bacteria. The ability to accumulate polyP intracellularly is common among different types of microorganisms (Kulaev, 1979). Bacteria certainly are numerically predominant in activated sludge, but higher organisms, algae, fungi, protozoa and invertebrates are also known to occur in the sludge.

Cells of the principal PAO were the largest cells abounding in the sludge. Yeast cells, even in spore form, are larger than bacterial cells, and numerous yeast species live in aquatic environments (Hagler \& Ahearn, 1987). Although typical yeast spores are bigger than the principal PAO cells, there are examples of fungal spores in the size range 1-2 $\mu \mathrm{m}$ (Kreger-van Rij \& Veenhuis, 1974; Asano et al., 1999). The cells of the principal PAO occurred in clusters as fungal spores often do, simply because of their mode of formation. In addition, cell-tocell adhesion and flocculation are usual among yeasts (Calleja, 1987). The oval-to-coccoid form of the PAO cells is typical of fungal spores, as is also their tendency towards swelling.

The first organism shown to contain polyP was the baker's yeast Saccharomyces cerevisiae (Liebermann, 1888). PolyP has since been found in several yeast species (Kulaev \& Vagabov, 1983). As accumulation of polyP and spore production serve the same goal, survival of the organism, it is not surprising that especially high polyP content in fungal cells has been found in the spores (Bajaj et al., 1954). Vegetative growth and full-scale metabolism cease temporarily in sporulation and the fungus goes over to a stationary state with reduced metabolism. Reduced metabolism of the clustered PAO was reported by Beacham et al. (1990) and reasons why polyP accumulation in BPR sludge, especially in a highly clustered $\mathrm{PAO}$, can be expected to take place under stationary growth conditions were discussed by Melasniemi et al. (1998).

\section{Cell surface with yeast attributes}

The cell envelope of the principal PAO was not of the character typical of bacteria. The cell wall of the principal PAO stained anomalously in Gram staining and it was not affected by the enzyme lysozyme, which degrades the peptidoglycan of most bacteria. Weak staining by the predominantly chitin-binding fluorescent dye calcofluor (Pringle, 1991) suggested the presence of chitin in the principal PAO. Chitin is a common constituent of fungal cell walls, being absent in bacteria. In the cell wall of $S$. cerevisiae spores the deacetylated analogue of chitin, chitosan, is shielded from efficient staining (Briza et al., 1988), whereas in asexual spores of Mucor rouxii the relative amount of chitin is low, only one-quarter of that in the vegetative cells (BartnickiGarcia, 1968). The presence of chitin-like $\beta-1,4-$ hexapyranose polysaccharide in the cell wall of the principal PAO was corroborated by the fact that the PAO cells were converted to spheroplasts by 'lysing enzymes', containing chitinase, cellulase and protease. This enzyme cocktail is commonly used for the digestion 
of yeast cell walls. The cell surface of the principal PAO also bound concanavalin A, a protein specifically binding to branched $\alpha$-mannans and $\alpha$-glucans (Tkacz et al., 1971). Consequently, the principal PAO should have on its surface either or both of these polysaccharides, characteristically found on the surface of yeasts.

\section{Morphological transformation to yeast-like cells}

Short-chain fatty acids are thought to play a central role in BPR (van Loosdrecht et al., 1997; Mino et al., 1998). The PAOs should thus be able to take up acetate and use it as a substrate for growth. In accordance with this, the principal PAO cells present in untreated sludge were transformed to considerably bigger cells with a different appearance, i.e. yeast spores germinated to produce vegetative yeast cells, when sludge was transferred to acetate minimal medium containing ampicillin. The size of the transformed PAO cells was clearly bigger than the size of any of the bacteria seen in the same medium containing cycloheximide, or any of the bacteria isolated from sludge of the same process in a previous study (Melasniemi et al., 1998). Further evidence of the nonbacterial nature of the PAO is given by the fact that the transformation took place in the presence of a bacterial antibiotic (ampicillin) and did not take place in the presence of a yeast antibiotic (cycloheximide). In the presence of cycloheximide, yeast spores lost their polyP, died and disappeared, whilst at the same time diverse bacteria started to grow and synthesize polyP de novo. In a rich medium favouring bacterial growth (e.g. nutrient broth), sludge disintegrated and bacteria took over the culture even in the absence of cycloheximide (data not shown). The difficulty of perceiving the simultaneous degradation and synthesis of polyP in sludge grown further in the laboratory, together with the fact that Acinetobacter is favoured by acetate and forms polyP in culture, has probably been a major factor contributing to the birth of the Acinetobacter hypothesis of BPR.

\section{Bacterial PAOs in BPR processes}

Considering the undisputed fact that many bacteria are capable of polyP accumulation, the idea of the involvement of several bacterial PAO groups in BPR (Mino et al., 1998) might well be true. This opinion is based on the results of culture-independent studies (e.g. Wagner et al., 1994; Bond et al., 1995, 1999; Kämpfer et al., 1996; Kawaharasaki et al., 1999), which have suggested $\beta$-proteobacteria, Gram-positive bacteria with a high $\mathrm{G}+\mathrm{C}$ content in their DNA and $\alpha$-proteobacteria as PAOs. However, the salient role of any bacterial group as PAOs in BPR taking place at actual wastewater treatment plants has as yet not been clearly proven. Although one may perhaps justifiably expect to find PAOs in higher numbers in BPR than in nonBPR sludge, mere enrichment of a specific bacterial group under BPR conditions does not imply that these bacteria were PAOs. Methods based on nucleotide sequences only can only give information on the phylogenetic structures of the communities studied. PolyP accumulation must be shown by other means.

We are aware of only four studies where PAOs have been assigned to a specific bacterial group by combining phylogenetic in situ data with microscopic observation of polyP. Two of the studies (Kawaharasaki et al., 1999; Bond et al., 1999) were based, however, on sequencing batch reactors fed in the laboratory with pure bacteriological culture media (synthetic waste waters), which, although dilute, were nonetheless totally soluble and of fixed formula. Only two of the studies (Wagner $e t$ al., 1994; Kämpfer et al., 1996) relate to processes (Phoredox and $\mathrm{A} / \mathrm{O}$, respectively) treating genuine waste water with an ever-fluctuating composition. In these studies metachromatic granules were found in cell morphotypes that bound the probe for high $G+C$ bacteria. With the exception of the Microthrix parvicella morphotype, the high $\mathrm{G}+\mathrm{C}$ morphotypes were, however, not described. In both cases polyP granules were especially evident in $M$. parvicella, a well-known filamentous polyP bacterium often associated with sludge bulking (Jenkins et al., 1993) and often encountered in BPR processes.

Neither Wagner et al. (1994) nor Kämpfer et al. (1996) reported polyP in the distinct grape-like clusters forming PAO that have so often been found at other BPR wastewater treatment plants to contain massive amounts of polyP. Thus, it seems that this PAO (or group of PAOs) has so far not been associated with any other bacterial group except (incorrectly) with Acinetobacter. The Acinetobacter hypotheses of BPR of the past two decades has become ever less attractive in recent years. However, the even more widely held presumption of the ubiquitously predominant role of prokaryotes, i.e. polyP bacteria, in BPR has not been challenged until now.

\section{ACKNOWLEDGEMENTS}

We thank the BNR project staff for their help. This study was supported by the Finnish National Technology Agency (TEKES) and the Maj and Tor Nessling Foundation.

\section{REFERENCES}

Allan, R. A. \& Miller, J. J. (1980). Influence of $S$-adenosylmethionine on DAPI induced fluorescence of polyphosphate in the yeast vacuole. Can J Microbiol 26, 912-920.

Asano, T., Kageyama, K. \& Hyakumachi, M. (1999). Surface disinfestation of resting spores of Plasmodiophora brassicae used to infect hairy roots of Brassica spp. Phytopathology 89, 314-319.

Auling, G., Pilz, F., Busse, H.-J., Karrasch, S., Streichan, M. \& Schön, G. (1991). Analysis of the polyphosphate-accumulating microflora in phosphorus-eliminating, anaerobic-aerobic activated sludge systems by using diaminopropane as a biomarker for rapid estimation of Acinetobacter spp. Appl Environ Microbiol 57, 3585-3592.

Bajaj, V., Damle, S. P. \& Krishnan, P. S. (1954). Phosphate metabolism of mold spores. I. Phosphate uptake by the spores of Aspergillus niger. Arch Biochem Biophys 50, 451-460.

Bartnicki-Garcia, S. (1968). Cell wall chemistry, morphogenesis and taxonomy. Annu Rev Microbiol 22, 87-108. 
Beacham, A. M., Seviour, R. J., Lindrea, K. C. \& Livingston, I. (1990). Genospecies diversity of Acinetobacter isolates obtained from a biological nutrient removal pilot plant of modified UCT configuration. Water Res 24, 23-29.

Bond, P. L., Hugenholz, P., Keller, J. \& Blackall, L. L. (1995). Bacterial community structures of phosphate-removing and nonphosphate-removing activated sludges from sequencing batch reactors. Appl Environ Microbiol 61, 1910-1916.

Bond, P. L., Erhart, R., Wagner, M., Keller, J. \& Blackall, L. L. (1999). Identification of some of the major groups of bacteria in efficient and nonefficient biological phosphorus removal activated sludge systems. Appl Environ Microbiol 65, 4077-4084.

Briza, P., Ellinger, A., Winkler, G. \& Breitenbach, M. (1988). Chemical composition of the yeast ascospore wall: the second outer layer consists of chitosan. J Biol Chem 263, 11569-11574.

Buchan, L. (1981). The location and nature of accumulated phosphorus in seven sludges from activated sludge plants which exhibited enhanced phosphorus removal. Water SA 7, 1-7.

Buchan, L. (1983). Possible biological mechanism of phosphorus removal. Water Sci Technol 15, 87-103.

Calleja, G. B. (1987). Cell aggregation. In The Yeasts, vol. 2, 2nd edn, pp. 165-238. Edited by A. H. Rose \& J. S. Harrison. London: Academic Press.

Cloete, T. E. \& Steyn, P. L. (1988). The role of Acinetobacter as a phosphorus removing agent in activated sludge. Water Res 22, 971-976.

Drews, G. (1983). Mikrobiologisches Practicum, 4th edn. Berlin: Springer-Verlag.

Duncan, A., Vasiliadis, G. E., Bayly, R. C., May, J. W. \& Raper, W. G. C. (1988). Genospecies of Acinetobacter isolated from activated sludge showing enhanced removal of phosphate during pilot-scale treatment of sewage. Biotechnol Lett 10, 831-836.

Fuhs, G. W. \& Chen, M. (1975). Microbiological basis of phosphate removal in the activated sludge process for the treatment of wastewater. Microb Ecol 2, 119-138.

Hagler, A. N. \& Ahearn, D. G. (1987). Ecology of aquatic yeasts. In The Yeasts, vol. 1, 2nd edn, pp. 181-206. Edited by A. H. Rose \& J. S. Harrison. London: Academic Press.

Hendrickson, D. A. \& Krenz, M. M. (1991). Reagents and stains. In Manual of Clinical Microbiology, 5th edn, pp. 1289-1314. Edited by A. Balows and others. Washington, DC: American Society for Microbiology.

Jenkins, D., Richard, M. G. \& Daigger, G. T. (1993). Activated sludge microbial features other than filaments. In Manual on the Causes and Control of Activated Sludge Bulking and Foaming, 2nd edn., pp. 62-68. Boca Raton, FL: Lewis Publishers.

Kämpfer, P., Erhart, R., Beimfohr, C., Böhringer, J., Wagner, M. \& Amann, R. (1996). Characterization of bacterial communities from activated sludge: culture-dependent numerical identification versus in situ identification using group- and genus-specific rRNAtargeted oligonucleotide probes. Microb Ecol 32, 101-121.

Kawaharasaki, M., Tanaka, H., Kanagawa, T. \& Nakamura, K. (1999). In situ identification of polyphosphate-accumulating bacteria in activated sludge by dual staining with rRNA-targeted oligonucleotide probes and 4',6-diamidino-2-phenylindol (DAPI) at a polyphosphate-probing concentration. Water Res 33, $257-265$.

Kotai J. (1971). Instructions for preparation of modified nutrient solution Z8 for algae. Blindern, Oslo, Norway: Norwegian Institute for Water Research (publication B-11/69).
Kreger-van Rij, N. J. W. \& Veenhuis, M. (1974). Spores and septa in the genus Dipodascus. Can J Bot 52, 1335-1338.

Kulaev, I. S. (1979). The Biochemistry of Inorganic Polyphosphates. Chichester: Wiley.

Kulaev, I. S. \& Vagabov, V. M. (1983). Polyphosphate metabolism in micro-organisms. Adv Microb Physiol 24, 83-171.

Liebermann, L. (1888). Ueber das Nucleïn der Hefe und künstliche Darstellung eines Nucleïns aus Eiweiss und Metaphosphorsäure. Ber Dtsch Chem Ges 21, 598-600.

van Loosdrecht, M. C. M., Hooijmans, C. M., Brdjanovic, D. \& Heijnen, J. J. (1997). Biological phosphate removal processes. Appl Microbiol Biotechnol 48, 289-296.

Lötter, L. H. \& Murphy, M. (1985). The identification of heterotrophic bacteria in an activated sludge plant with particular reference to polyphosphate accumulation. Water SA 11, 179-184.

Melasniemi, H., Hernesmaa, A., Pauli, A. S.-L., Rantanen, P. \& Salkinoja-Salonen, M. (1998). Comparative analysis of biological phosphate removal (BPR) and non-BPR activated sludge bacterial communities with particular reference to Acinetobacter. J Ind Microbiol Biotechnol 21, 300-306.

Mino, T., van Loosdrecht, M. C. M. \& Heijnen, J. J. (1998). Microbiology and biochemistry of the enhanced biological phosphate removal process. Water Res 32, 3193-3207.

Nakamura, K., Hiraishi, A., Yoshimi, Y., Kawaharasaki, M., Masuda, K. \& Kamagata, Y. (1995). Microlunatus phosphovorus gen. nov., sp. nov., a new Gram-positive polyphosphate-accumulating bacterium isolated from activated sludge. Int J Syst Bacteriol 45, 17-22.

Pringle, J. R. (1991). Staining of bud scars and other cell wall chitin with calcofluor. Methods Enzymol 194, 732-735.

Srinath, E. G., Sastry, C. A. \& Pillai, S. C. (1959). Rapid removal of phosphorus from sewage by activated sludge. Experientia 15, 339-340.

Stante, L., Cellamare, C. M., Malaspina, F., Bortone, G. \& Tilche, A. (1997). Biological phosphorus removal by pure culture of Lampropedia spp. Water Res 31, 1317-1324.

Streichan, M., Golecki, J. R. \& Schön, G. (1990). Polyphosphateaccumulating bacteria from sewage plants with different processes for biological phosphorus removal. FEMS Microbiol Ecol 73, 113-124.

Tandoi, V., Majone, M., May, J. \& Ramadori, R. (1998). The behaviour of polyphosphate accumulating Acinetobacter isolates in an anaerobic-aerobic chemostat. Water Res 32, 2903-2912.

Tkacz, J. S., Cybulska, E. B. \& Lampen, J. O. (1971). Specific staining of wall mannan in yeast cells with fluorescein-conjugated concanavalin A. J Bacteriol 105, 1-5.

Toerien, D. F., Gerber, A., Lötter, L. H. \& Cloete, T. E. (1990). Enhanced biological phosphorus removal in activated sludge systems. Adv Microb Ecol 11, 173-230.

Towner, K. J. (1992). The genus Acinetobacter. In The Procaryotes, 2nd edn, pp. 3137-3143. Edited by A. Balows and others. New York: Springer.

Wagner, M., Erhart, R., Manz, W., Amann, R., Lemmer, H., Wedi, D. \& Schleifer, K.-H. (1994). Development of an rRNA-targeted oligonucleotide probe specific for the genus Acinetobacter and its application for in situ monitoring in activated sludge. Appl Environ Microbiol 60, 792-800.

Received 8 September 1999; revised 22 November 1999; accepted 9 December 1999. 